\title{
A failed invasion? Commercially introduced pollinators in Southern France*
}

\author{
Thomas C. INGS ${ }^{1}$, Nicola L. INGS ${ }^{1}$, Lars CHITTKA $^{1}$, Pierre RASMONT ${ }^{2}$ \\ ${ }^{1}$ School of Biological \& Chemical Sciences, Queen Mary University of London, Mile End Road, \\ London E1 4NS, UK \\ ${ }^{2}$ Université de Mons-Hainaut, av. du champ de Mars 6, 7000 Mons, Belgium
}

Received 19 January 2009 - Revised 2 March 2009 - Accepted 6 March 2009

\begin{abstract}
The natural diversity of Bombus terrestris subspecies could be under threat from the commercialisation of bumblebees. Therefore, to determine whether commercially imported bumblebees are able to establish and spread, we carried out long-term observations of bumblebees in southern France. Our surveys occurred before, during, and after the importation (between 1989 and 1996) of thousands of colonies of the Sardinian subspecies B. t. sassaricus. Queens and males of B.t. sassaricus were observed foraging outside commercial greenhouses in 1991, 1993, and 1994 and feral workers were observed foraging on native vegetation nearly two years after the importation of B. t. sassaricus ceased. However, no B. t. sassaricus, or F1 hybrids were observed after 1998. We conclude that B. t. sassaricus remains inconspicuous in France and competition from the three native subspecies may have prevented it from becoming invasive. However, genetic interference through introgression cannot be ruled out.
\end{abstract}

\section{Bombus terrestris sassaricus / bumble bee trade / establishment / introduced subspecies /} niche availability

\section{INTRODUCTION}

Biological invasions resulting from the introduction of non-native organisms generate potentially large economic and ecological costs (Pimentel, 2002; Perrings et al., 2005; Pimentel et al., 2005). Despite this, strong economic pressures are driving the introduction of non-native pollinators, particularly honeybees and bumblebees, throughout the world (Delaplane and Mayer, 2000; Thorp 2003; Velthuis and van Doorn, 2006). Given the scale of these introductions, as well as documented population declines in many natural pollinators across the globe (Kearns et al., 1998; Sarospataki et al., 2005; Steffan-Dewenter et al., 2005; Williams, 2005;

Corresponding author: T.C. Ings,

t.c.ings@qmul.ac.uk

* Manuscript editor: Jean-Noël Tasei
Biesmeijer et al., 2006), and the potential invasiveness of social insects (Moller, 1996; Schneider et al., 2004), it is surprising that relatively few studies have actually attempted to monitor the establishment and spread of non-native pollinators (Ruz, 2002; Diniz et al., 2003; Matsumura, 2003; Inari et al., 2005; Schmid-Hempel et al., 2007). A common feature of these, and other studies on invasive organisms, is that they concern introduced species. However, the introduction of non-native subspecies (or populations) is more likely to impact on population diversity through hybridisation and introgression, and possibly competitive exclusion (Schneider et al., 2004; Moritz et al., 2005), than the introduction of non-native species.

Bumblebees provide an excellent model system to explore these risks further. After honeybees, bumblebees are the most important species for crop pollination (Delaplane 
and Mayer, 2000). Furthermore, the trade in bumblebees involves introductions of both non-native species and subspecies (Inari et al., 2005; Hingston, 2006; Ings et al., 2006; Inoue et al., 2008; Rasmont et al., 2008).

One of the most important commercially reared bumblebee species, particularly for the European and Asian markets, is Bombus terrestris (L). Worldwide, nearly one million colonies of $B$. terrestris are being used by growers each year (Velthuis and van Doorn, 2006). To date, B. terrestris has been imported into over 57 countries, including 16 outside of its native range (Ings, 2007). In fact, $B$. terrestris has now become established in the wild in at least two of these countries as the result of recent commercial introductions: Japan (Matsumura, 2003; Inari et al., 2005; Inoue et al., 2008) and Chile (Ruz, 2002). B. terrestris also became well established in New Zealand following purposeful introductions during late 19th and early 20th centuries, and more recently has spread into Tasmania, although it is not known whether the latter introduction was intentional or accidental (Schmid-Hempel et al., 2007). Within Europe, the situation is more complex because the commercial trade in $B$. terrestris involves introduction of non-native subspecies (Ings et al., 2005b; Velthuis and van Doorn, 2006) which could have consequences for the natural population diversity of the species in Europe (Ortiz-Sánchez, 1993; Estoup et al., 1996; Widmer et al., 1998).

There are nine subspecies of B. terrestris found within Europe and N. Africa (Rasmont et al., 2008). The continental (e.g. French and German) and island (e.g. Sardinian) populations are recognised as distinct subspecies because they differ significantly in their genotype (Estoup et al., 1996; Widmer et al., 1998) and phenotype; e.g. coat colour and colour preferences (Chittka et al., 2004), pheromones (Coppée et al., 2008), and behaviourally related traits such as foraging ability (Ings et al., 2005a; Ings et al., 2006). In fact, bumblebee breeders have utilised this diversity during the commercialisation of bumblebees by carefully selecting the best suited subspecies for their breeding programs (Velthuis, 2002; Velthuis and van Doorn, 2006). One of these was B. $t$. sassaricus Tournier, 1890, which naturally occurs in Sardinia. The initial breeding program was very successful and thousands of colonies of $B$. $t$. sassaricus were produced and shipped outside their native range into southern mainland Europe, including southern France, between 1989 and 1996 to pollinate tomatoes (Ings et al., 2005a; Velthuis and van Doorn, 2006). Since then, commercial breeders have largely been producing and exporting $B$. $t$. dalmatinus (Velthuis and van Doorn, 2006).

The first step in assessing the potential impacts of introducing non-native subspecies is to determine if they are able to establish themselves in the wild (i.e. establish colonies outside greenhouses) and spread beyond the areas into which they have been directly introduced. The importation of B.t. sassaricus into France provides an excellent opportunity to do this. Although the natural population of B.t. sassaricus is geographically isolated from the mainland French populations, climatic conditions of N. Sardinia and Mediterranean France are quite similar. Furthermore, a comprehensive survey of the bumblebees of France was undertaken by Rasmont (1988) prior to importation of $B$. $t$. sassaricus. He established that three subspecies of $B$. terrestris naturally coexist in southern France: B. t. terrestris (L. 1758), B. t. lusitanicus (Krüger 1956 [= ferrugineus auct. nec. Schmiedeknecht, 1878]) and B.t. dalmatinus Dalla Torre (1882) (Fig. 1). They exhibit the same annual cycle as B.t. sassaricus and B.t. xanthopus (Kriechbaumer, 1870) from Corsica (Ferton, 1901; Krausse, 1910), i.e. they have two generations per year, one in the spring and another in the autumn/winter (Rasmont, 1985; Duhayon and Rasmont, 1993). Finally, distinct differences in coat colour patterns of Sardinian and mainland subspecies (described fully in the methods) allow them to be readily distinguished in the field.

Therefore, in this study we use long-term observations of $B$. terrestris in southern France (covering a 15 year period since the initial importation of B.t. sassaricus) coupled with recent targeted surveys, to track the potential establishment and spread of an introduced non-native bumblebee subspecies. 


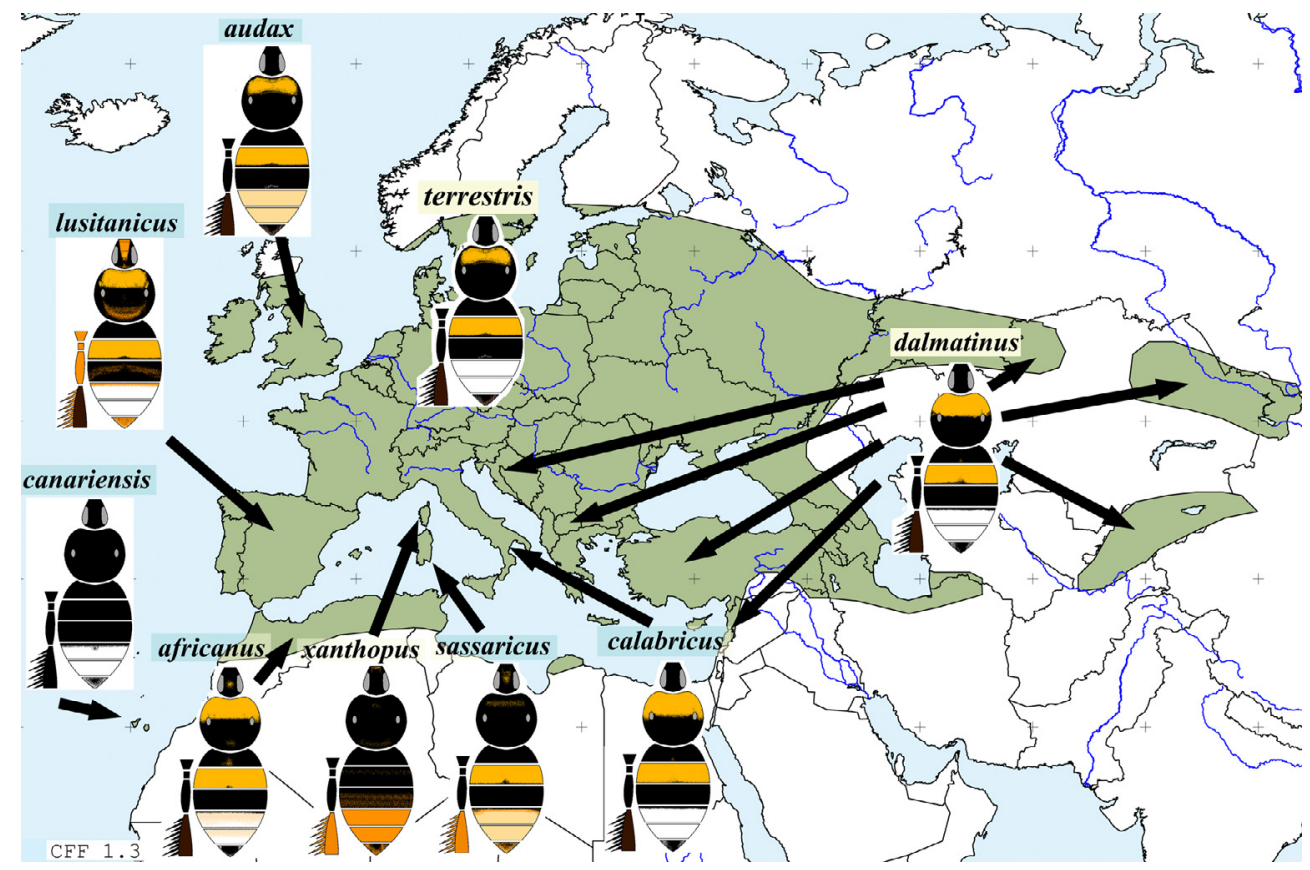

Figure 1. The natural distribution of $B$. terrestris subspecies. The shaded area indicates the range over which $B$. terrestris occurs and the arrows point to the approximate centres of distribution of the nine subspecies. This figure was reproduced with permission from Rasmont et al. (2008).

\section{MATERIALS AND METHODS}

\subsection{Study subspecies}

Five subspecies of Bombus terrestris L. occur along the southern coast of France and on the Tyrrhenian islands (Sardinia, Corsica and Elba): B. t. dalmatinus, B. t. terrestris, B. t. lusitanicus, B. t. sassaricus and B. t. xanthopus. The subspecies from the islands show highly distinct colour patterns from those on the mainland (Rasmont et al., 2008). In particular, the Sardinian subspecies of $B$. terrestris can easily be distinguished from all other subspecies found in southern France. The native French subspecies (B. t. terrestris, B. t. lusitanicus and B. t. dalmatinus) have a black coat with a yellow collar at the front of the thorax, a yellow band on the front of the abdomen (which has a white tip), and black legs (although B. t. lusitanicus has black legs with reddish-brown hair). However, B. t. sassaricus females (workers and queens) have no yellow band on the thorax and the cuticle on their legs is conspicuously reddish-brown. These characters therefore make field identification of B.t. sassaricus easy (Fig. 1). Subspecies of B. terrestris are able to hybridise in the laboratory and in the wild (Rasmont and Adamski, 1996; Rasmont and Quaranta, 1997; Rasmont et al., 2008). We have observed intermediate forms of the three native subspecies in France, indicating that they also hybridise naturally, if infrequently. Coat coloration seems to be controlled by a single locus (Velthuis and van Doorn, 2006) and the red colouration of the legs of B. t. sassaricus is carried forward into hybrids, with $50 \%$ of males from hybrid matings and all F1 workers maintaining this character (Chittka and Wells, 2004; Velthuis and van Doorn, 2006).

\subsection{Area surveyed}

During the course of this study (1988-2004) we surveyed all departments of Continental France adjacent to the Mediterranean, from West to East: Pyrénées-Orientales (Postcode 66), Aude (11), Hérault (34), Gard (30), Bouches-du-Rhône (13), Vaucluse (84), Var (83) and Alpes-Maritimes (06) (see Figs. 2-5). This area encompasses the entire range of the autumn/winter generation of $B$. 


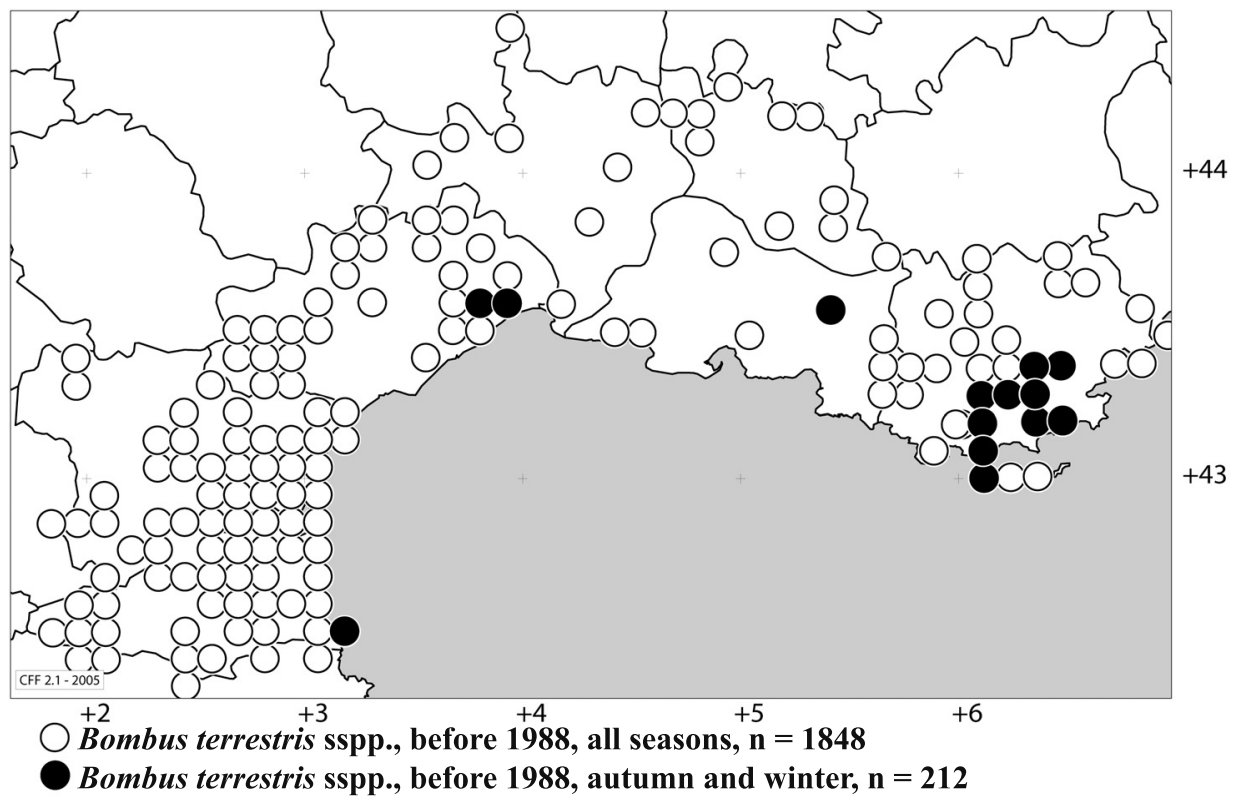

Figure 2. Pre 1988 observations of native B. terrestris subspecies in southern France prior to the importation of B.t. sassaricus.

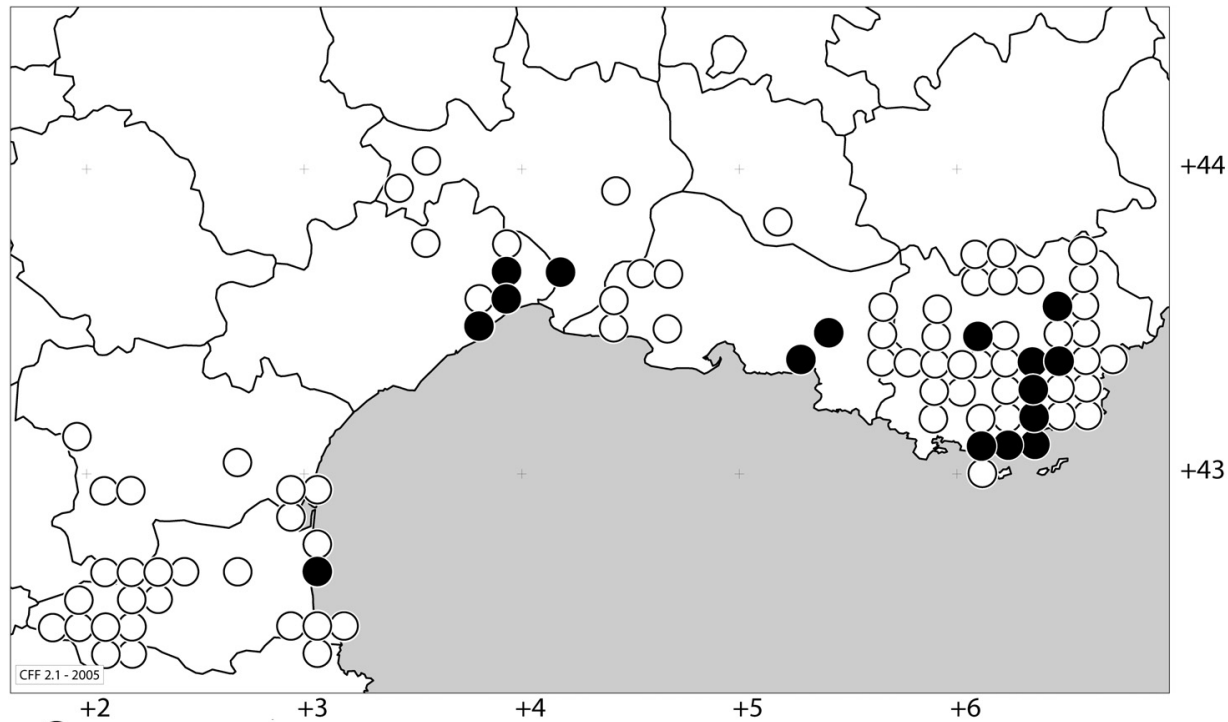

Bombus terrestris sspp., 1988-2002, all seasons, $n=7946$

Bombus terrestris sspp., 1988-2002, autumn and winter, $n=5926$

Figure 3. Observations of B. terrestris subspecies made between 1988 and 2002. NB. B. t. sassaricus was recorded at four localities (see Fig. 5). 


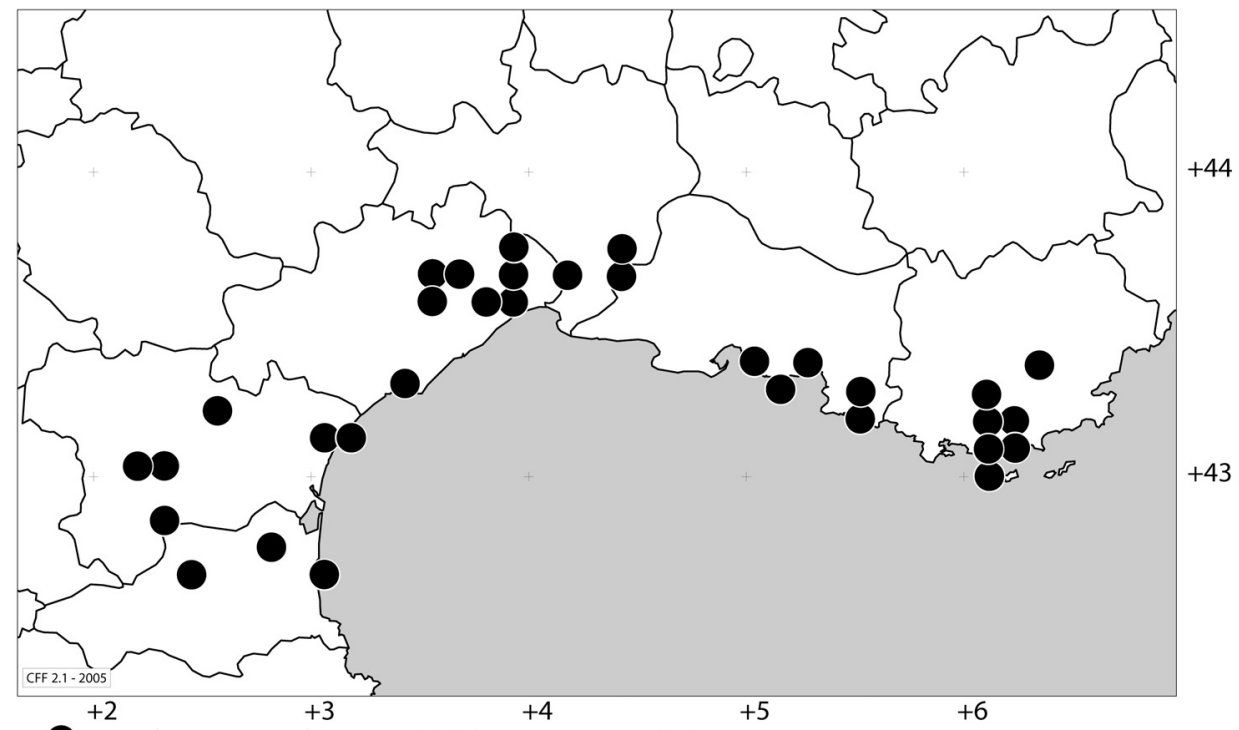

Bombus terrestris sspp., 2004 survey, $n=493$

Figure 4. Records of B. terrestris subspecies collected during 2004. NB. no B. t. sassaricus were found.

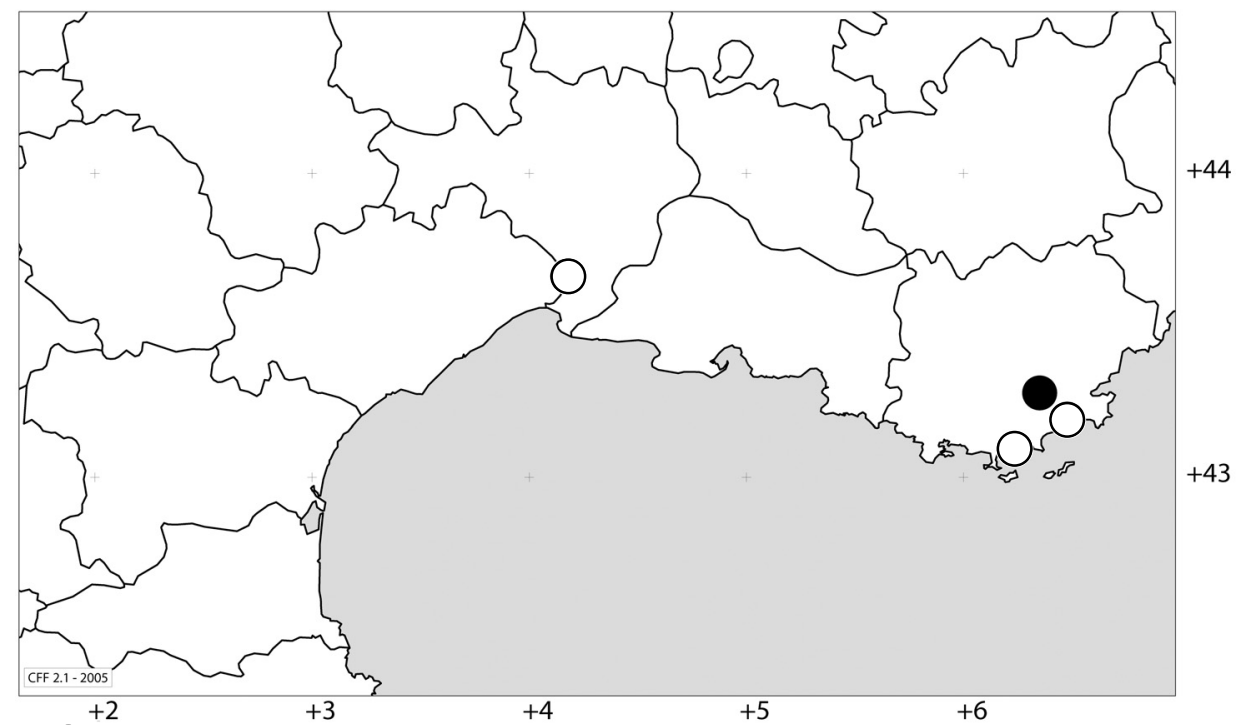

Bombus terrestris sassaricus, near to $(<10 \mathrm{Km})$ glasshouses, $\mathrm{n}=6$

Bombus terrestris sassaricus, far from ( $>30 \mathrm{Km}$ ) glasshouses, $n=4$

Figure 5. Location of B. t. sassaricus records collected between 1993 and 1998. 
terrestris in continental France (Rasmont, 1985; Duhayon and Rasmont, 1993).

\subsection{Data collection}

\subsection{1. $1988-2002$}

Since 1988, PR made ad hoc visits of 1-2 months every year in the Mediterranean region of France (Fig. 3), typically in October, November, December, April, May, July and August. Most of these visits (April, May) involved intensive insect collection by students from the Université de MonsHainaut, as part of a Zoology and Ecology field course. The October-November trips were devoted to collecting queens for bumblebee breeding and the December and July observations were part of short collecting excursions during holidays. Bombus terrestris is in aestivation during August in the Mediterranean basin. During this time a total of 7946 B. terrestris specimens were examined.

\subsubsection{Survey of 2004}

To follow up previous observations, and determine whether B.t. sassaricus had indeed become established in southern France, extensive searches were carried out in 2004 along the length of the French Mediterranean coastline (Fig. 4), from near Hyères $\left(43^{\circ} 08^{\prime} \mathrm{N} 6^{\circ} 07^{\prime} \mathrm{E}\right)$ in the east to near Perpignan $\left(42^{\circ} 42^{\prime} \mathrm{N} 2^{\circ} 53^{\prime} \mathrm{E}\right)$ in the west. Three visits were made to encompass different generations of $B$. terrestris. The first visit occurred in May (9th to 20th) to coincide with peak worker activity of the spring generation. A second survey was carried out near Montpellier and Perpignan in October (18th to 21 st) to coincide with peak activity of nest founding queens after the first autumn rains. Finally, a return visit to the Montpellier region was made in December (19th to 23rd) to coincide with peak worker activity of colonies founded by the generation of queens observed in October.

During these periods over 100 flower rich sites at 32 locations were monitored by two observers for the presence of bumblebees. A total of $478 \mathrm{~B}$. terrestris specimens were examined. We used either standard bee walks (e.g. Pollard, 1977; Banaszak, 1980) or fixed observations, depending on the habitat type. Bee walks entailed walking slowly $\left(\sim 1 \mathrm{~m} \mathrm{~s}^{-1}\right)$ along a linear habitat (e.g. roadside verge or flowering hedge) identifying and recording all visible bumblebees (typically within $2 \mathrm{~m}$ either side of the transect). For habitats where flowers were in discrete patches (e.g. flowering shrubs), individual patches (typically 4 by $4 \mathrm{~m}$ ) were observed (10-20 minutes combined observation time per patch - up to 1 hour if bumblebees were detected). All sites were monitored during dry weather. During October and December, all bees were captured and marked, by placing a dot of white correction fluid $\left(\right.$ Tippex $^{\circledR}$ ) on the thorax, to avoid re-recording the same individuals.

When a bumblebee was observed it was scored as a queen, worker or male and identified as nonnative B. t. sassaricus (all black thorax and red legs) or native French B. terrestris sl. (yellow banded thorax and black legs). Queens and workers of the native French $B$. terrestris showing distinct characteristics were further split into subspecies: B. t. terrestris (narrow yellow band on the thorax), B.t. dalmatinus (wide yellow band on its thorax) and B. $t$. lusitanicus (distinctive reddish-brown hairs on its legs).

\section{RESULTS}

\subsection{Extensive surveys 1988 to 2002}

\subsubsection{Before importation of B.t. sassaricus (pre 1989)}

The original survey by Rasmont (1988), which occurred largely before the mass import of $B$. $t$. sassaricus, revealed the co-occurrence of three native subspecies of $B$. terrestris (B. $t$. terrestris, B. t. dalmatinus and B. t. lusitanicus) in the Mediterranean coastal regions of France (Fig. 2). However, although 1848 individuals (mainly those cited by Rasmont, 1985) were observed (Fig. 2) across all departments $(66,34,30,13,84$ and 83), no specimens of $B$. $t$. sassaricus were found (mean proportion in population $=0$, upper $95 \%$ Confidence Interval (Wilson score interval: Newcombe 1998) $=0.0021)$.

\subsubsection{During importation of B.t. sassaricus (1989-1996)}

During the second survey between 1988 and 2002, a further 7946 B. terrestris were 
recorded across all surveyed departments (Fig. 3). The majority of these records (5626 bees) were from the autumn/winter generation (recorded between September 21 and January 31) and were observed visiting Salpichroa origanifolia (Lam.) Baillon and Arbutus unedo L. A small number of B.t. sassaricus (6 in total between 1991 and 1994) were observed for the first time at three different locations in areas close $(<10 \mathrm{~km})$ to commercial greenhouses (Tab. I, Fig. 5). One of the males observed in 1994 showed characteristics of both B. t. terrestris and $B$. t. sassaricus.

\subsubsection{After importation of $\mathbf{B} . \mathbf{t}$. sassaricus ceased (1998)}

In 1998, two years after the last colonies of B.t. sassaricus were imported into France, several B. $t$. sassaricus workers were observed foraging alongside native subspecies in an isolated garden surrounded by forest close to Gonfaron, Var (Tab. I, Fig. 5) more than $30 \mathrm{~km}$ from the nearest commercial greenhouses (which typically occur along the coastal plains). However, despite frequent return visits in all seasons, no more B. t. sassaricus have been recorded at this location.

\subsection{Survey of 2004}

\subsubsection{May}

Bumblebee abundance was low in May 2004, with less than 200 B. terrestris being recorded, despite extensive searches being carried out at 75 flower rich patches during good weather. Furthermore, B. terrestris was only recorded at just over half (39 out of 75) of the flower rich patches surveyed (Fig. 4). Most records of $B$. terrestris were workers (152), although some queens (12) and a few males (7) were seen. All three native subspecies (B. $t$. terrestris, B. t. lusitanicus, B. t. dalmatinus and various intermediate forms (putative hybrids)) were recorded. However, no B. terrestris sassaricus, or F1 hybrids, were found in a total sample of 171 bees (mean proportion $=0$, upper $95 \%$ Confidence Interval $=0.022$ ).

\subsubsection{October}

A large number of queens (135) and a few males (20) of the three native subspecies were observed at six $S$. origanifolia and two $A$. unedo sites in October (Fig. 4). About $45 \%$ of the 60 queens recorded at the largest $S$. origanifolia location (Mas de St-Michel, near Aimargue) were B. t. lusitanicus, $33.3 \%$ B. t. terrestris and $16.7 \%$ B. t. dalmatinus. However, no B. terrestris sassaricus, or F1 hybrids, were found in a total sample of 155 bees (mean proportion $=0$, upper $95 \%$ Confidence Interval $=$ 0.024).

\subsubsection{December}

During the final survey in December, B. terrestris was recorded at all of the six locations near Montpellier. Mostly workers (135), a few males (16) and one queen were observed foraging on A. unedo, Erica multiflora L. and Rosmarinus officinalis L. About two thirds of bees recorded were either B. t. terrestris or B. $t$. dalmatinus (they were not separated on this occasion) with the remaining third being $B . t$. lusitanicus. However, no B. terrestris sassaricus, or F1 hybrids, were found in a total sample of 152 bees (mean proportion $=0$, upper $95 \%$ Confidence Interval $=0.025$ )

\section{DISCUSSION}

This study is one of the first to document the escape, temporary establishment and apparently failed invasion of an imported subspecies. Extensive surveys of southern France carried out during the 1990's revealed that males and queens (i.e. reproductively active castes) of the commercially imported, nonnative subspecies B.t. sassaricus were escaping into the wild. More importantly, by 1998 B. $t$. sassaricus appeared to have become naturalised in at least one wild area of southern France far from greenhouses. However, in subsequent surveys we were unable to detect the presence of $B$. $t$. sassaricus, indicating that it has been unable to persist, possibly through competitive exclusion by the three native subspecies. Alternatively, B. t. sassaricus may be 


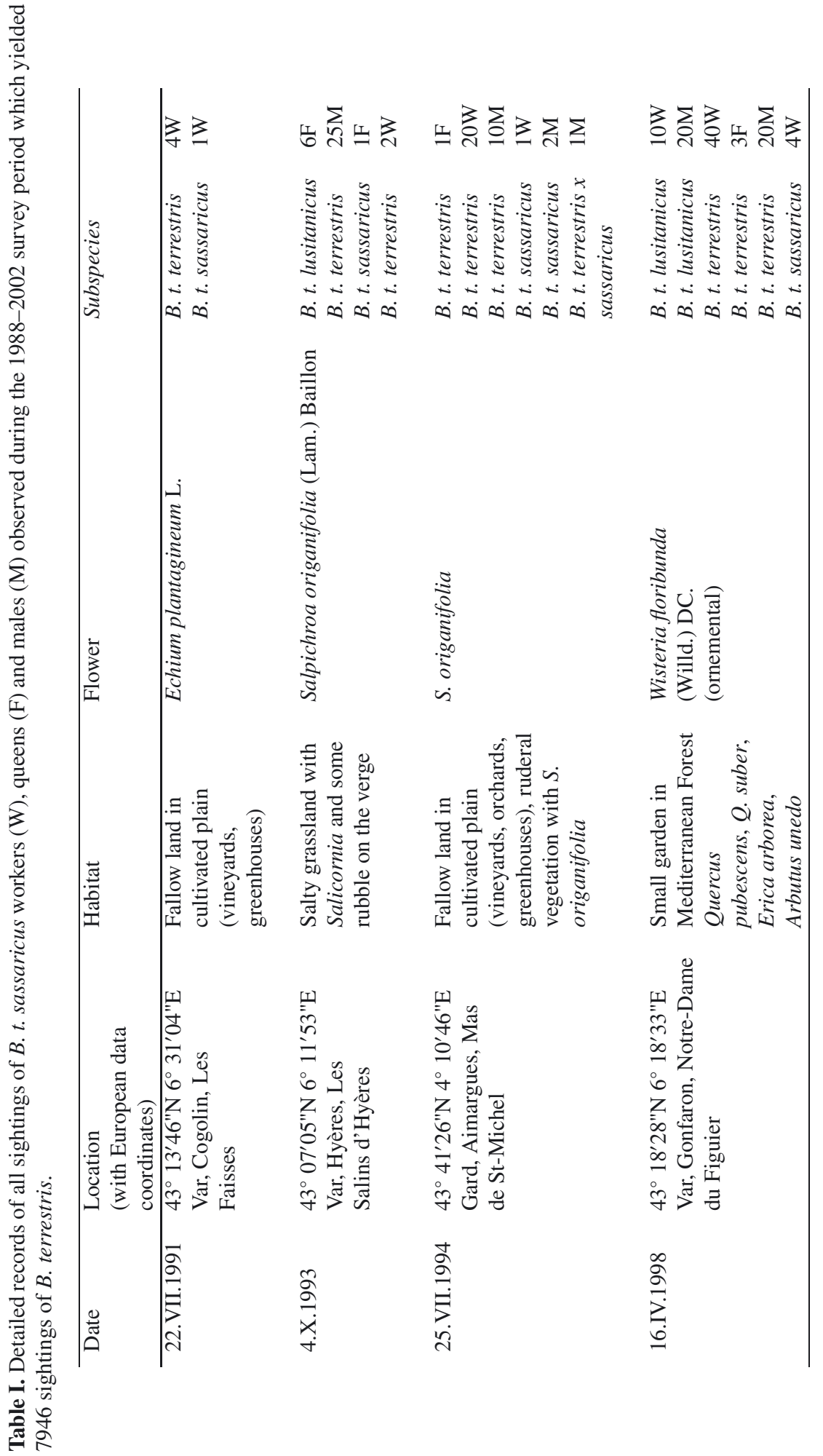


present in very low numbers or its appearance may have become indistinguishable from the other native subspecies as a result of frequent hybridisation.

The structure of B. terrestris populations is complex: insular forms (including $B$. $t$. sassaricus and B. t. xanthopus from the Tyrrhenian Islands and $B$. $t$. canariensis from the Canary Islands) are significantly genetically differentiated from mainland forms (Estoup et al., 1996; Widmer et al., 1998; Rasmont et al., 2008). Several of the subspecies are able to hybridise, both under laboratory (Ings et al. 2005b) and natural conditions (Rasmont and Adamski, 1996; Rasmont and Quaranta, 1997). Therefore, moving subspecies, especially insular ones, into regions where they are not native could have important implications for the genetic diversity of $B$. terrestris.

Discovery of both male and queen B.t. sassaricus close to commercial greenhouses in the 1990's showed that they were escaping in to the wild. B.t. sassaricus will hybridise with B. t. xanthopus in southern Corsica, although hybrids are very rare (Rasmont and Adamski, 1996), so it is conceivable that hybridisation would be a problem in southern France. However, only one male showing mixed characters, i.e. a putative hybrid, was discovered near to greenhouses during this study (Tab. I).

Although low numbers of B. $t$. sassaricus were observed outside greenhouses, large quantities (thousands) of $B . t$. sassaricus colonies were used in southern France over 8 years (1989-1996). Release of a few individuals from each colony every year (possibly several times a year) would represent a high propagule pressure, which is known to increase the probability of establishment by alien species (Kolar and Lodge, 2001). Furthermore, B. terrestris appears to be able to establish viable populations from a very small pool of foundress queens (Buttermore et al., 1998). Southern France also provides B. $t$. sassaricus with suitable habitats containing important biota necessary to sustain its autumn/winter generation. Notably, extensive $A$. unedo populations, a common food plant for B. t. sassaricus in northern Sardinia (Krausse, 1910), are present in the Massif des Maures to the north-west of Saint Tropez and the Massif de l'Arboussas to the north-west of Montpellier. We therefore expected that B. t. sassaricus should readily become established in southern France.

Our expectations were met to some extent in 1998 when workers of B. $t$. sassaricus were observed foraging in an isolated area of the Massif des Maures. This observation occurred nearly two years after the importation of B. t. sassaricus ceased, and was more than 30 kilometres from the nearest commercial greenhouses. Clearly B. t. sassaricus had established feral colonies in the region and had persisted for at least 2 years. However, no further observations of $B$. $t$. sassaricus, or visible F1 hybrids, have been made since, despite continued visits to the same area and extensive surveys along the south coast of France (between Hyères in the east and Perpignan in the west: Fig. 4). This leads us to ask why no more B. t. sassaricus were seen again.

A problem with surveys is that it is easier to show presence than it is to conclusively show absence. Survey effort, i.e. area covered, observation hours and number of observations is important. In our study, the surveys undertaken between 1988 and 2002, when a few specimens of $B$. $t$. sassaricus were observed, covered a larger area and involved many more observations (7946 compared to 493) than the 2004 survey. It is therefore possible that $B$. $t$. sassaricus were missed in the 2004 surveys. Furthermore, low bumblebee densities occurred during the surveys in May 2004: B. terrestris was only recorded at 39 out of 75 suitable habitat patches. This scarcity, which may have been a consequence of the extreme dryness in 2003, might have affected our ability to detect B. t. sassaricus. However, our surveys incorporated areas close to commercial greenhouses, where feral colonies are most likely to be found (Inari et al., 2005), and areas where B. t. sassaricus had previously been recorded (e.g. near Aimargue). The surveys also targeted areas of habitat containing favoured food plants of B.t. sassaricus (e.g. A. unedo in the Massif des Maures and near Montpellier). The surveys in October and December also increased the total area covered and the number of bees identified. Yet, no B. t. sassaricus or its F1 hybrids were seen, 
even amongst the large number of queens that were recorded near Aimargue. More importantly, the upper estimate for the proportion of B.t. sassaricus present in the population of B. terrestris, i.e. those potentially missed was only $0.8 \%$ for the combined 2004 survey.

It is possible that no B. $t$. sassaricus were found because hybridisation with other subspecies during the last decade has led to loss of the distinctive colouration of B. t. sassaricus. Coat colouration seems to be controlled by a single locus (Velthuis and van Doorn, 2006), so continued mixing with other native subspecies over at least 16 generations (two generations per year) could remove colour variation from the resident population. Yet, the three native subspecies recorded in this study still maintained their natural colour forms despite low levels of hybridisation among subspecies. Therefore, although southern France appears to be a $B$. terrestris hybrid zone (only $B$. $t$. terrestris is present in central and northern France), a reasonably large degree of reproductive isolation must be occurring, for example through non-random mating (Ings et al., 2005b; Coppée et al., 2008). Clearly the only way to fully resolve this issue would be to sample the population of $B$. terrestris close to historical importation sites and to use molecular techniques to determine subspecies membership and/or presence of hybrids beyond the F1 generation, if it is still possible.

If we conclude, as our data suggest, that $B$. $t$. sassaricus was briefly established in the wild in France but was not able to persist as a pure subspecies, we are prompted to ask: why not? B. terrestris has readily become established in several countries outside its native range as result of intentional or accidental introductions (e.g. in New Zealand: Hopkins, 1914; Chile: Ruz, 2002; and Japan: Inari et al., 2005). However, the key difference in these countries is that $B$. terrestris is a non-native species that may be able to utilise a slightly different niche to native species, whereas in France it is a non-native subspecies which shares a very similar niche to the native subspecies already present. Furthermore, in Tasmania, $B$. terrestris is able to utilise both native and introduced plants (Hingston, 2005). Thus, niche availability, which is believed to be im- portant in invasion success (Shea and Chesson, 2002; Le Breton et al., 2005), is perhaps a limiting factor in France.

B. $t$. xanthopus seems to have been able to cross the $33 \mathrm{~km}$ distance between the Capraia and the Elba Islands, where it hybridizes with B. t. terrestris (Rasmont and Quaranta, 1997). B. t. sassaricus is easily able to cross the $12 \mathrm{~km}$ from Sardinia to Corsica where it hybridises, albeit rarely, with the native Corsican subspecies B. t. xanthopus. However, B. t. sassaricus has not been able to gain a foothold in Corsica, and hybrids are restricted to the southern coast (Rasmont and Adamski, 1996). This suggests that vagrant $B$. t. sassaricus and hybrid offspring are competitively excluded by the native $B$. $t$. xanthopus. Niche overlap between $B$. $t$. sassaricus and the three subspecies native to the French mainland is likely to be the same. In contrast, in New Zealand and Tasmania there are no native species of bumblebee, although $B$. terrestris may have to compete with other native bees for floral resources (Hingston and McQuillan, 1999). Furthermore, it has been suggested that introduced bumblebees in these countries rely heavily on plants introduced from Europe that are not utilised by the native bee fauna (Stout et al., 2002; Goulson and Hanley, 2004).

Our long-term study has documented the brief establishment and apparently failed invasion of a non-native bumblebee subspecies in France. B. t. sassaricus is no longer present, or its population density is negligible in comparison to native subspecies. We conclude that the inability of imported B.t. sassaricus to become properly established in France reflects competitive exclusion by the three native subspecies. However, a number of questions regarding the impact of the release of non-native subspecies into the wild remain open and need to be addressed in the future. In particular, it is necessary to use molecular techniques (e.g. Murray et al., 2008) to confirm that B. t. sassaricus has not disrupted the native subspecies gene pool.

\section{ACKNOWLEDGEMENTS}

TI was supported by the University of London Central Research Fund (grant CRFT1C7R) and 
the Natural Environment Research Council (grant NE/D012813/1). LC was supported by a grant from the British Ecological Society (SEPG 2267) and PR was supported by the Belgian Fonds National de la Recherche Scientifique and Fonds de la Recherche Fondamentale et Collective (mainly grant 2.4.564.06.F). We would like to thank JeanNoël Tasei and two anonymous reviewers for their helpful comments on an earlier version of the manuscript.

\section{Échec d'une invasion? Celle des pollinisateurs Bombus introduits commercialement dans le Sud de la France.}

Bombus terrestris sassaricus / commercialisation de Bombus / installation de populations / sousespèce introduite / pollinisateurs / compétition intraspécifique/niche écologique

\section{Zusammenfassung - Eine fehlgeschlagene In- vasion? Kommerziell eingeführte Bestäuber in Südfrankreich. Obwohl die Kommerzialisierung der Hummelbestäubung ökonomisch wichtig ist, gibt es Befürchtungen, dass sich dieser Handel ne- gativ auf einheimische Hummelpopulationen aus- wirkt (Velthuis und van Doorn, 2006). Innerhalb Europas werden einige Rassen von B. terrestris in großer Zahl in Gebiete eingeführt, in denen sie nicht heimisch sind. Es ist daher wichtig festzustellen, ob eingeführte Rassen sich im Freiland etablieren kön- nen und eventuell invasiv werden. Das Ziel unserer Arbeit war es, eine mögliche Ansiedlung der einge- führten sardischen Hummelrasse B. t. sassaricus in Südfrankreich zu dokumentieren. \\ Wir führten eine Langzeitstudie durch, die kurz vor der Einfuhr von B. t. sassaricus begann (zwi- schen 1989 und 1996) und 8 Jahre nach dem Ende des Imports abgeschlossen wurde. Während dieser Zeit untersuchten wir alle ans Mittelmeer angren- zende Departements des französischen Festlandes (Abb. 2-5).}

Männchen und Königinnen von $B$. t. sassaricus entkamen ins Freiland und wurden in den Jahren 1991, 1993 und 1994 beim Sammeln außerhalb der Gewächshäuser beobachtet (Abb. 5). Wir fanden auch einige Arbeiterinnen in einer verwilderten Gegend nahe Gonfaron, Var, viele Kilometer vom nächsten Gewächshaus entfernt und fast zwei Jahre nachdem die Einfuhr von B. $t$. sassaricus beendet worden war. Allerdings wurden trotz fortlaufender Suche in der Nähe von Gonfaron und an 32 anderen Orten zwischen Hyères im Osten und Perpignan im Westen (Abb. 4) keine weiteren B. t. sassaricus mehr gefunden.

Unsere Ergebnisse zeigen eindeutig, dass kommerziell eingeführte Hummeln ins Freiland entkommen sind und in der Lage waren, sich einzubürgern.
Allerdings scheinen verwilderte Populationen von B. $t$. sassaricus nach Beendigung des Imports nicht länger als zwei Jahre zu bestehen. Diese Ergebnisse sind überraschend wenn man berücksichtigt, dass $B$. $t$. sassaricus in Südfrankreich ein vertrautes Habitat vorfindet und dass $B$. terrestris in Ländern weit außerhalb des natürlichen Verbreitungsgebietes zur invasiven Art geworden ist (z.B. Japan). Wir vermuten, dass die Konkurrenz durch drei einheimische Rassen verhindert hat, dass B. t. sassaricus in Frankreich Fuß fassen konnte, im Gegensatz zur Situation in Japan, wo B. terrestris sich als neue Art etabliert hat. Bevor wir aber abschließend feststellen, dass die Auswirkungen durch den Import von $B$. $t$. sassaricus vernachlässigbar sind, müssen wir noch überprüfen, ob die Populationsstruktur von $B$. terrestris in Frankreich durch Hybridisierungen von B. t. sassaricus mit einheimischen Rassen verändert wurde.

\section{Bombus terrestris sassaricus / Hummelimport / Ansiedlung / eingeführte Rassen / Nischenver- fügbarkeit}

\section{REFERENCES}

Banaszak J. (1980) Studies on methods of censusing the numbers of bees (Hymenoptera, Apoidea), Pol. Ecol. Studies 6, 355-365.

Biesmeijer J.C., Roberts S.P.M., Reemer M., Ohlemuller R., Edwards M., Peeters T., Schaffers A.P., Potts S.G., Kleukers R., Thomas C.D., Settele J., Kunin W.E. (2006) Parallel declines in pollinators and insect-pollinated plants in Britain and the Netherlands, Science 313, 351-354.

Buttermore R.E., Pomeroy N., Hobson W., Semmens T., Hart R. (1998) Assessment of the genetic base of Tasmanian bumble bees (Bombus terrestris) for development as pollination agents, J. Apic. Res. 37, 23-25.

Chittka L., Wells H. (2004) Color vision in bees: mechanisms, ecology and evolution, in: Prete F. (Ed.), Complex Worlds from Simpler Nervous Systems, MIT Press, Cambridge, pp. 169-191.

Chittka L., Ings T.C., Raine N.E. (2004) Chance and adaptation in the evolution of island bumblebee behaviour, Pop. Ecol. 46, 243-251.

Coppée A., Terzo M., Valterova, Rasmont P. (2008) Intraspecific variation of the cephalic labial gland secretions in Bombus terrestris (L.) (Hymenoptera: Apidae), Chem. Biodiv. 5, 2654-2661.

Delaplane K.S., Mayer D.F. (2000) Crop pollination by bees, CABI Publishing, Wallingford.

Diniz N.M., Soares A.E.E., Sheppard W.S., Del Lama M.A. (2003) Genetic structure of honeybee populations from southern Brazil and Uruguay, Genet. Mol. Biol. 26, 47-52.

Duhayon G., Rasmont P. (1993) La phénologie des grands Apoïdes dans le massif des Maures 
(France, Var), in: Lhonoré J., Maurin H., Guilbot R., Keith P. (Eds.), C.R. séminaire sur l'inventaire et la cartographie des invertébrés comme contribution à la gestion des milieux naturels français, pp. 165-168, Muséum National d'Histoire Naturelle, Paris.

Estoup A., Solignac M., Cornuet J.-M., Goudet J., Scholl A. (1996) Genetic differentiation of continental and island populations of Bombus terrestris (Hymenoptera: Apidae) in Europe, Mol. Ecol. 5, 19-31.

Ferton R. (1901) Les Hyménoptères de Corse (Apiaires, Sphégides, Pompilides et Vespides), C.R. A.F.A.S., Congrès d'Ajaccio, 1901; also in Ferton C. (1923) La vie des abeilles et des guêpes, Chiron, Paris.

Goulson D., Hanley M.E. (2004) Distribution and forage use of exotic bumblebees in South Island, New Zealand, N. Z. J. Ecol. 28, 225-232.

Hingston A.B. (2005) Does the introduced bumblebee, Bombus terrestris (Apidae), prefer flowers of introduced or native plants in Australia? Aust. J. Zool. 53, 29-34.

Hingston A.B. (2006) Is the exotic bumblebee Bombus terrestris really invading Tasmanian native vegetation? J. Insect Conserv. 10, 289-293.

Hingston A.B., McQuillan P.B. (1999) Displacement of Tasmanian native megachilid bees by the recently introduced bumblebee Bombus terrestris (Linnaeus, 1758) (Hymenoptera: Apidae), Aust. J. Zool. 47, 59-65.

Hopkins I. (1914) History of the humble-bee in New Zealand: its introduction and results, in: New Zealand Department of Agriculture and Industry Comments, pp. 13-29.

Inari N., Nagamitsu T., Kenta T., Goka K., Hiura T. (2005) Spatial and temporal pattern of introduced Bombus terrestris abundance in Hokkaido, Japan, and its potential impact on native bumblebees, Pop. Ecol. 47, 77-82.

Ings T.C. (2007) Bombus terrestris, humble pollinator or assiduous invader? PhD, University of London.

Ings T.C., Schikora J., Chittka L. (2005a) Bumblebees, humble pollinators or assiduous invaders? A population comparison of foraging performance in Bombus terrestris, Oecologia 144, 508-516.

Ings T.C., Raine N.E., Chittka L. (2005b) Mating preference in the commercially imported bumblebee species Bombus terrestris in Britain (Hymenoptera: Apidae), Entomol. Gen. 28, 233238.

Ings T.C., Ward N.L., Chittka L. (2006) Can commercially imported bumble bees out-compete their native conspecifics? J. Appl. Ecol. 43, 940-948.

Inoue M., Yokoyama J., Washitani I. (2008) Displacement of Japanese native bumblebees by the recently introduced Bombus terrestris (L.) (Hymenoptera: Apidae), J. Insect Conserv. 12, 135-146.

Kearns C.A., Inouye D.W., Waser N.M. (1998) Endangered mutualisms: The Conservation of
Plant-Pollinator Interactions, Annu. Rev. Ecol., Evol. Syst. 29, 83-112.

Kolar C.S., Lodge D.M. (2001) Progress in invasion biology: predicting invaders, Trends Ecol. Evol. 16, 199-204.

Krausse A.H. (1910) Hummelleben auf Sardinien im Winter, Entomol. Rundsch. 27, 23-24.

Le Breton J., Jourdan H., Chazeau J., Orivel J., Dejean A. (2005) Niche opportunity and ant invasion: the case of Wasmannia auropunctata in a New Caledonian rain forest, J. Trop. Ecol. 21, 93-98.

Matsumura C. (2003) Nationwide monitoring of the invasion of the alien bumblebee, Bombus terrestris L. (Hymenoptera: Apidae) in Japan (sixth report), Jap. J. Conserv. Ecol., 8.

Moller H. (1996) Lessons for invasion theory from social insects, Biol. Conserv. 78, 125-142.

Moritz R.F.A., Hartel S., Neumann P. (2005) Global invasions of the western honeybee (Apis mellifera) and the consequences for biodiversity, Ecoscience 12, 289-301.

Murray T.E., Fitzpatrick Ú., Brown M., Paxton R. (2008) Cryptic species diversity in a widespread bumble bee complex revealed using mitochondrial DNA RFLPs, Conserv. Genet. 9, 653-666.

Newcombe R.G. (1998) Two-sided confidence intervals for the single proportion: comparison of seven methods, Stat. Med. 17, 857-872.

Ortiz-Sánchez F.J. (1993) Una nueva introducción irregular de abejorros en el sur de España: Bombus terrestris xanthopus (Kriechbaumer, 1870) (Hymenoptera, Apidae), Entomofauna - Z . Entomol. 14, 470-471.

Perrings C., Dehnen-Schmutz K., Touza J., Williamson M. (2005) How to manage biological invasions under globalization, Trends Ecol. Evol. 20, 212-215.

Pimentel D. (2002) Biological invasions: economic and environmental costs of alien plant, animal, and microbe species, CRC Press, p. 369.

Pimentel D., Zuniga R., Morrison D. (2005) Update on the environmental and economic costs associated with alien-invasive species in the United States, Ecol. Econ. 52, 273-288.

Pollard E. (1977) A method for assessing changes in the abundance of butterflies, Biol. Conserv. 12, 115-134.

Rasmont P. (1985) Bombus terrestris (L.) (Hymenoptera, Apidae) dans le Massif des Maures (France, Var), une génération d'hiver? Bull. Ann. Soc. R. Belge Entomol. 120, 359-363.

Rasmont P. (1988) Monographie écologique et zoogéographique des Bourdons de France et de Belgique (Hymenoptera, Apidae, Bombinae), Thèse Doctorat Sciences Agronomiques, Fac. Sci. Agron. État.

Rasmont P., Adamski A. (1996) Les bourdons de la Corse (Hymenoptera, Apoidea, Bombinae), Notes fauniques de Gembloux 31, 3-87. 
Rasmont P., Quaranta M. (1997) I Bombi dell'Arcipelago Toscano, Boll. Soc. Entomol. Ital. 129, 31-38.

Rasmont P., Coppée A., Michez D., De Meulemeester T. (2008) An overview of the Bombus terrestris (L. 1758) subspecies (Hymenoptera: Apidae), Ann. Soc. Entomol. Fr. 44, 243-250.

Ruz L. (2002) Bee pollinators introduced to Chile: a review, in: Kevan P.G., Imperatriz-Fonesca V.L. (Eds.), Pollinating Bees. The conservation link between agriculture and Nature, Ministry of Environment, Brasil, pp. 155-167.

Sarospataki M., Novak J., Molnar V. (2005) Assessing the threatened status of bumble bee species (Hymenoptera: Apidae) in Hungary, Central Europe, Biodivers. Conserv. 14, 2437-2446.

Schmid-Hempel P., Schmid-Hempel R., Brunner P.C., Seeman O.D., Allen G.R. (2007) Invasion success of the bumblebee, Bombus terrestris, despite a drastic genetic bottleneck, Heredity 99, 414-422.

Schneider S.S., Hoffman G.D., Smith D.R. (2004) The African honey bee: Factors contributing to a successful biological invasion, Annu. Rev. Entomol. 49, 351-376.

Shea K., Chesson P. (2002) Community ecology theory as a framework for biological invasions, Trends Ecol. Evol. 17, 170-176.

Steffan-Dewenter I., Potts S.G., Packer L. (2005) Pollinator diversity and crop pollination services are at risk, Trends Ecol. Evol. 20, 651.
Stout J.C., Kells A.R., Goulson D. (2002) Pollination of the invasive exotic shrub Lupinus arboreus (Fabaceae) by introduced bees in Tasmania, Biol. Conserv. 106, 425-434.

Thorp R.W. (2003) Bumble bees (Hymenoptera: Apidae): Commercial use and environmental concerns, in: Strickler K., Cane J.H. (Eds.), For non native crops, whence pollinators of the future? Entomological Society of America, Lanham, pp. 21-40.

Velthuis H.H.W. (2002) The historical background of the domestication of the bumble-bee, Bombus terrestris, and its introduction in agriculture, in: Strickler K., Cane J.H. (Eds.), Pollinating Bees - The conservation link between agriculture and nature Ministry of Environment, Brasil, pp. 177184.

Velthuis H.H.W., van Doorn A. (2006) A century of advances in bumblebee domestication and the economic and environmental aspects of its commercialization for pollination, Apidologie 37, 421451.

Widmer A., Schmid-Hempel P., Estoup A., Scholl A. (1998) Population genetic structure and colonization history of Bombus terrestris s.I. (Hymenoptera: Apidae) from the Canary Islands and Madeira, Heredity 81, 563-572.

Williams P. (2005) Does specialization explain rarity and decline British bumblebees? - A response to Goulson et al., Biol. Conserv. 122, 33-43. 